\section{An analysis of skills and qualities required by LIS employers 2004-2005}

\author{
Paula Younger
}

\section{The Author}

A chartered librarian and qualified teacher, Paula Younger has worked since 1990 in a wide range of information and education environments. For the last 4 years, Paula has worked for the Ministry of Defence in medical and science libraries in the south of England, gaining familiarity with a wide range of e-resources, licensing arrangements and firewall settings. She will shortly be joining the NHS as the Electronic Resources Librarian at the Royal Devon and Exeter Hospital.

\section{Abstract}

Between April 2004 and March 2005 data was collated from I,000 LIS vacancies advertised in CILIP Gazette. The wording in the advertisements was analysed and a record made of skills requested. Skills were then grouped into the following areas: specialist library skills; transferable skills relating to management; general transferable skills - customer facing; general transferable skills - non-customer facing; working patterns and availability; and personal characteristics. Skills are analysed across the whole sample and grouped by larger sector, e.g. schools, FE/HE. The skills requested are also analysed by approximate level of post, ranging from library assistant to director and above. A brief attempt is also made to put the current skills situation into context in the light of the imminent retirement of many 'baby boomer' librarians. Some trends are observed, and some of the implications for both applicants and employers are also outlined.
\end{abstract}

\section{Background}

The library sector, like dozens of others, is facing a time of unprecedented change in the demographics of its workforce in the next decade. According to Lynch in her brief overview of 2001 US newspaper articles highlighting current trends (2002) and her work for the American Library Association in the same year, almost three quarters $(68 \%)$ of today's librarians will have retired by 2017 .

There is some evidence, both anecdotal and backed up by more systematic research, that for some time now recruiters have been experiencing difficulties in attracting appropriately-qualified staff to interview. In her research for the North West Regional Archive Council and Libraries North West, where questionnaires were distributed to libraries to gather key data including skills gaps and shortages in the region, Hamblin (2002) suggested that it is particularly difficult to attract candidates for fixed-term or project-style posts. The sectors targeted in this study included NHS, FE and HE libraries and information units, law libraries, public libraries and archives, private archives, business and government libraries.

Usherwood and Proctor's research on the public library workforce (2001), carried out for the Centre for the Public Library and Information in Society at the University of Sheffield, suggests that the situation will have worsened within the next decade. The study incorporated an extensive literature search, surveys of public library authorities in the UK, focus groups, and consultation with stakeholders. Published by re:Source (2001), it suggested that within 10 years, demand for candidates in the public library sector may begin to outstrip the supply of good quality applicants. A report by the public sector trade union UNISON on behalf of the culture media and sport committee inquiry into government policy on public libraries (c. 2001) also highlighted problems in recruiting.

Whether there actually is a skills shortage in the library field is a moot point however. Some individuals looking for work view the current 'librarian shortage' in a completely different 
way, as can be seen from weblogs and anecdotal evidence. As one American librarian outlines, "Location does have a lot to do with whether there's a shortage of applications. Overall, however, for the amount of ENTRY-LEVEL jobs open, I believe there are far more MLSs". The writer goes on to say that what actually appears to be happening is that entry level positions are not opening up whereas management posts are experiencing difficulties in recruiting. Despite the ALA's official view that there is a lack of qualified librarians, other statistics on their site also indicate that the surfeit of posts is not at the entry level.

Jacobson (2002) also found in her brief analysis of employers' experiences in academic circles in the US that employers had a wide choice of candidates at the entry level. One university had 120 applicants for one entry-level post. Conversely, however, when a more specialised serials librarian vacancy arose, despite advertising across the United States on three separate occasions only two or three people applied.

The problems are not limited only to the UK or the US, as Teece (2003) indicated in his study on behalf of the Australian Library and Information Association in which he collated statistics based on information given to the association. He pointed out that " $56 \%$ of librarians and $52 \%$ of library technicians are over 45 years of age", $20 \%$ of librarians were already past the minimum retirement age, and less than a quarter of qualified librarians were under the age of 35 .

\section{Succession planning, leadership and the wider demographic picture}

Bentley (2004) is amongst many who are aware that the baby boomer generation is about to hit retirement age, as he makes clear in a newspaper article for the Guardian. 'Baby boomer' refers to the 17 million people born in Britain between 1945 and 1965.

The majority of the world's Boomers were born in Canada, Australia, New Zealand and the United States between 1946 and 1964. In
Canada over $25 \%$ of the population is in this group (Whitmell, 2002). This generation is disproportionately represented in libraries in the US and Canada, and although it is difficult to find comparable information for the UK, what can be found suggests a similar profile in the UK. A Semlac report (2004) took an overview of the current library situation in the south east of England, for example, found in an analysis of CILIP members in the south east region that $29 \%$ of the regional membership was aged 50 or over. This rose to $33.3 \%$ if members aged over 65 and "not known" are removed. The likelihood is that the true figure is much higher, since many library staff are not members of CILIP.

As Whitmell (2002) has discussed, many baby boomers have stayed with the same library for the past 25 to 30 years. In the 1990s, as Generation X could vouch, new hires in libraries reduced drastically. Whitmell points out that "The issue of succession planning, or replacing the large number of those anticipated to be retiring and leaving professional and nonprofessional positions in the next few years, is slowly coming to the forefront of the library community. In fact, however, succession planning only usually becomes an issue when a member of staff leaves".

The next generation, meanwhile, Generation X, is much smaller in size. As Baby Boomers live longer and the cost of living spirals ever upwards in the civilised Western world, the dream of early retirement recedes for the Boomers. Some Generation X-ers are finding themselves under-employed. They may also find they are having to wait longer and longer for middle management and senior management posts. Although these posts are likely to become vacant in the next ten to fifteen years, in the meantime, Generation $\mathrm{X}$ are not always able to develop the leadership skills required for those future posts. The Baby Boomers often regard Generation $\mathrm{X}$ as a cynical, self-serving generation lacking in discipline and loyalty. The truth is rather more complex. Lankard (1995) gives a brief literature review of Generation $\mathrm{X}$ and how it differs from the Baby Boomers, incorporating differing viewpoints from a range 
of authors. Generation $\mathrm{X}$ is characterised by a higher level of technological literacy and a coming of age when a linear career path no longer exists. Whitmell also suggests that Generation X look for a flatter structure within the workforce than the hierarchical approach taken by the Boomers: "Overall this group is characterized as being unimpressed with authority and will treat the chief librarian as they would the receptionist."

Rodgers (2004) has observed that, "with the baby boomers firmly entrenched in their roles and seemingly unwilling to budge, aspiring CIOs from Generation X - the eldest of whom turn 43 this year - are feeling left out in the cold." It is even predicted by some experts that there will be a leadership vacuum, particularly in the US. There are 76 million boomers in the USA, with only 50 million Generation X-ers to replace them. This relates to a newspaper article where he interviewed existing members of Generation X.

In the meantime, Generation $\mathrm{Y}$ is hot on the heels of Generation X. When the Baby Boomers do retire, it will be interesting to see whether the middle and senior management roles currently occupied by the Baby Boomers will still exist. How many of them rely heavily on traditional library skills and are likely to be swept away by new technology? It is possible that in a drive to save money on the wage bill (usually the largest single outlay of any organisation), employers may look to replace these postholders with qualified librarians, or with competent graduates (or non-graduates) who are able to use the Internet. It will therefore be equally interesting to see if management and leadership skip a generation and employers go straight to Generation Y. Finally, if it is not possible for employers to find the skills they require, will employers take a more flexible approach to retaining baby boomers, perhaps in a part-time or consultant role?

For libraries, this has implications for their ability to attract - and retain - suitably skilled staff. Whitmell, again, suggested that anecdotal evidence indicates that many managers are concerned about their ability to retain good staff, particularly when so many are hired on temporary contracts. There are also some indications that some professional library jobs are being filled by non-librarians.

Indeed, the whole skills landscape of library work is beginning to change, as Wilder (2000) has observed in his report for the Association of Research Libraries, where he published information on unpublished, demographic data sets compiled from 1990s and 1994 salary surveys of the ARL. The 1998 updating of the information on these skills in 110 university member libraries meant that the information could be updated, to take a clearer snapshot of the situation.

Between 1990 and 1998 the number of functional specialists hired in US libraries increased by $72 \%$. Interestingly, although perhaps not surprisingly given that $61 \%$ of hires in this period were for a systems-related job, almost half of the new hires (44\%) in this sector were male, compared to just over a quarter in other categories $(28 \%)$. The number of years of experience in this sector was also lower than in other areas, at an average of 4.6 years - although again, given the relatively new focus of this subject area, this is not particularly surprising.

This paper examines a selection of advertisements in the UK with a view to establishing which skills are most frequently requested, and whether there are any significant differences between sectors.

\section{Methodology}

One thousand advertisements for LIS posts published between April 2004 and March 2005 were examined and analysed. The advertisements were published in the Chartered Institute for Library and Information Professionals Gazette. The Gazette is one of the main sources of job advertisements for the Library Profession within the UK. The Gazette is published fortnightly and is a member benefit for all members of the Chartered Institute of Library and Information Professionals (the merged member organisation of the former Library Association and the Institute of 
Information Scientists). The print publication has a national distribution within the United Kingdom. In addition the website is accessible world-wide.

Advertisements were chosen from at least two and up to three editions of the publication for each month between April 2004 and March 2005. All advertisements in these selected editions were included in the sample. Where an agency had advertised more than one post in an advertisement, each individual job title was included in the sample. Where an employer had publicised more than one post in the same advertisement, again, each job title was entered separately into the database for analysis. Where there was more than one post with exactly the same job title listed with the same employer in the same advertisement only one instance was included in the database, unless there was additional information included. 'Librarian Children's and Young People' and 'Librarian Lifelong Learning' in the same advertisement, for example, would count as two entries. 'Librarian - Children's and Young People (2 posts)', however, was only included in the database once.

Advertisements in the Gazette usually include details of job title, salary band, location and employer, and the skills required. There are some exceptions to this: many agencies, for example, also choose to advertise in the Gazette and of necessity their advertisements are shorter than most of those posted by employers directly. For each of these issues each individual advertisement was summarised in an Access database. The posts included job-share, parttime, temporary, permanent, and full-time, and were spread throughout the United Kingdom.

Initially the advertisements were examined for skills which regularly recurred (more than ten times in each issue). As details of more advertisements were added to the database, this was refined, with skills grouped together where possible. The wording in advertisements was analysed and a record made of skills requested, for example communication skills or teaching/user education skills.
ICT skills requested by employers ranged from fluency in MS Office applications to a general level of IT literacy. ICT skills in this study refer to transferable ICT skills, such as the ability to use Microsoft Office, which would be equally valid whether within or outside a library or information setting. For the purposes of the research, this heading did not include more specialised database or IT skills such as programming, or library catalogue systems administrator ability or experience: these were detailed separately.

Where requested, particular levels of education or qualifications were also recorded. These included, for example, a degree, a postgraduate diploma, the European Computer Driving Licence.

The geographical location and skill sector of advertisements were also recorded. The number of years of experience requested was also recorded where this was specifically stated. For the purposes of this study, the posts have been grouped into approximate levels, which are:

- Library Assistant

- Senior paraprofessional (e.g. Senior Library Assistant)

- Professional (Assistant Librarian)

- Professional (Librarian)

- Manager

- Senior Manager/Senior Librarian

- Researcher/specialist, and posts that do not easily fall into one of the other 7 categories

- Director and above

A skill was only recorded as being requested if it was explicitly stated in the advertisement. Information from each advertisement was input into an Access database and the data compared across sectors and levels of post. Some of the person specifications requested in the advertisements were not so much skills as personal circumstances and abilities, e.g. can be mobile, has own transport, is able to work weekends/evenings. Many of the skills and qualities requested cannot be easily measured. How, for example, does one measure flexibility? Some advertisements specified a degree but not necessarily an Information Science degree. 
To allow for clearer comparison across sectors, the skills were grouped into the following areas:

- Specialist library skills, which it is unlikely that posts in other sectors would specify, such as cataloguing, stock selection, or knowledge of a particular library housekeeping system.

- Transferable skills relating to management. Presentation skills have been included in this section as a skill which managers are often required to demonstrate but which, in most cases, library assistants would not be expected to show.

- General transferable skills. This section includes skills such as customer service, interpersonal and communication skills, which are equally relevant wherever an employee might work.

- Working patterns and availability (including car ownership and/or a driving licence)

- Personal characteristics, such as flexibility and enthusiasm.

\section{Advertisements by sector}

The data on the advertisements collected was broken down by sector, as shown below. Where 'Education' is used as a heading, this referred to advertisements with council education headquarters, national partnerships, or learning and skills councils rather than to $\mathrm{HE}$, FE, or Schools.

\begin{tabular}{|c|c|c|}
\hline Sector & $\begin{array}{l}\text { No of vacancies } \\
\text { in this sample }\end{array}$ & \%age \\
\hline $\mathrm{HE}$ & 239 & 24 \\
\hline Public & 225 & 22 \\
\hline NHS/Health & 78 & 8 \\
\hline School & 68 & 7 \\
\hline FE & 66 & 7 \\
\hline Not stated & 66 & 7 \\
\hline Government & 51 & 5 \\
\hline Private/commercial & 54 & 5 \\
\hline Law & 45 & 4 \\
\hline Charity & 20 & 2 \\
\hline Professional Body & 18 & 2 \\
\hline National libraries & 14 & 1.4 \\
\hline Finance & 13 & 1.2 \\
\hline Museums & 11 & 1 \\
\hline Prisons and police & 10 & 1 \\
\hline Education & 9 & 1 \\
\hline Media & 8 & 1 \\
\hline $\mathrm{FE} / \mathrm{HE}$ & 4 & 0.4 \\
\hline
\end{tabular}

Table 1 Percentage of advertisements by sector

There are 18 sectors in total represented in this sample. Only eight of those sectors accounted for five per cent or more of advertised posts, with three sectors (HE; Public; NHS/Health) accounting for over half of all vacancies in this research (54\%). As can be seen, almost a quarter of all advertised posts $(24 \%)$ in this sample are in the HE sector. Public libraries run a close second, with $22 \%$. NHS and Health libraries are next, with only eight per cent of the total.

There were particular difficulties with the 'not stated/miscellaneous' sector. In some cases, there was a clue in the job title as to the particular sector. The likelihood is, for example, 
that 'Asian Collections Librarian' referred to a post in either the public sector or the academic world, but it was by no means certain. In other cases, the job titles offered no clue to the sector at all, when, for example, employers needed 'Project Cataloguers (Online Project)' or 'Team Librarian'. In some cases the employer was stated, but it was difficult to establish the sector affiliation of the organisation concerned. Posts were advertised, for example, with SWMLAC and EEMLAC, with a Chamber of Commerce, and with a Cathedral. The 'other' category applied where only one instance was found in the sample. Examples include research councils, "FE/HE", and VSO.

The skills requested were grouped by sector to make the results more meaningful. From here, it is possible to see within particular sectors where skills appear to be proportionately more important.
The extremely small percentage of the posts advertised in some categories, however, makes it very difficult to draw any firm conclusions. For those sectors where the numbers of vacancies advertised are small, further research over a longer period of time, or including a wider range of advertisement sources may increase the number of vacancies in those categories. This in turn might yield more conclusive findings.

\section{Overall analysis of skills requested: specialised library skills}

The chart below shows what percentage of vacancies in the entire sample requested particular library skills.

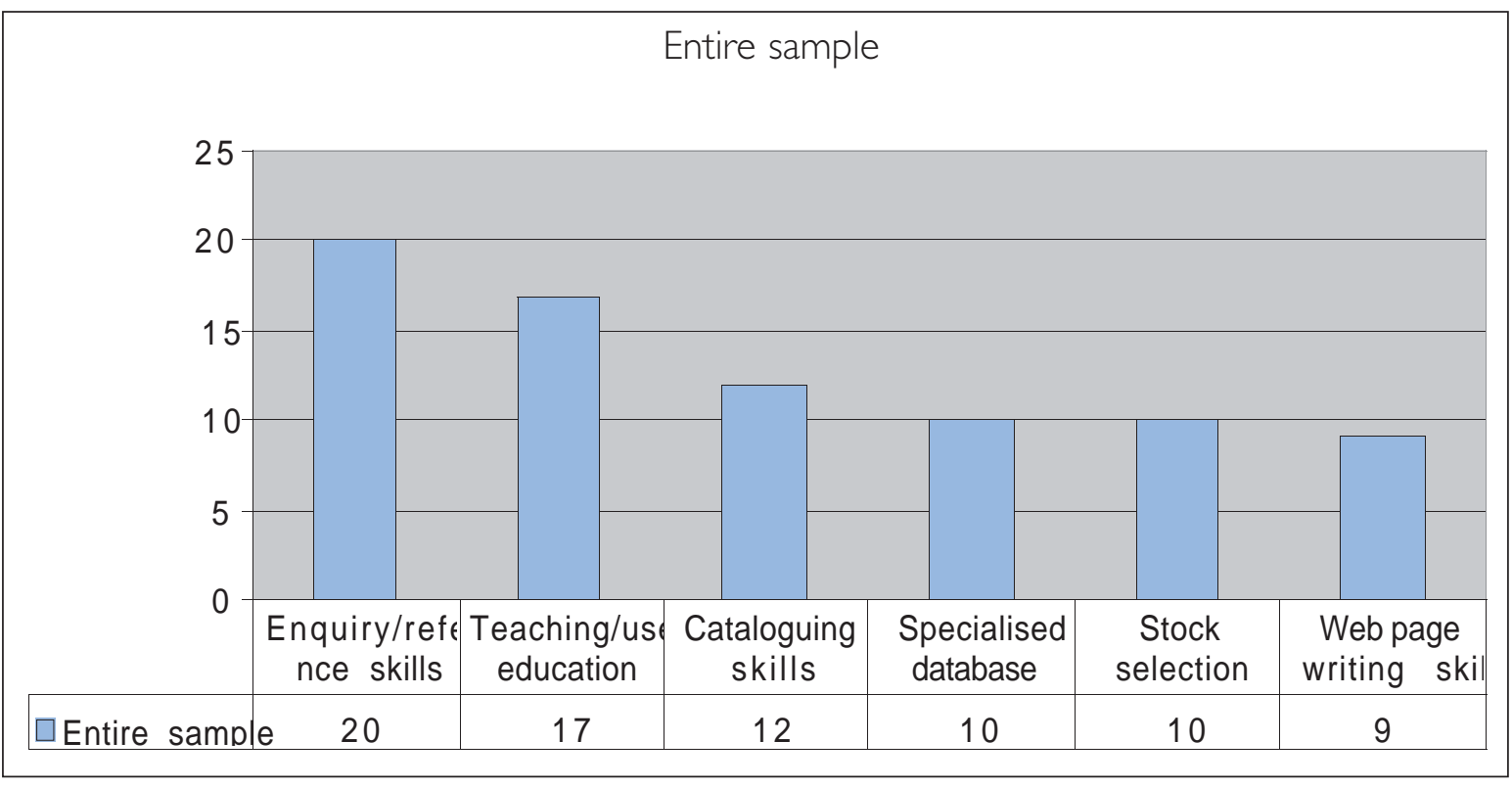

Fig. 1 Percentage of Library Specific Skills requested - complete sample

Overall, as can be seen, the most popular skill in this category was enquiry and reference skills, requested in one fifth of all advertisements. This was closely followed by teaching/user education, with web page writing skills the least likely to be requested in this category (although still requested in $9 \%$ of advertisements). 
The table below shows, for each sector, what percentage of advertisements in particular sectors specified a particular library skill. HE, public libraries, and health account for over half of all the vacancies advertised in this sample. The entire sample numbers are also given for comparison. In other sectors, which are far less well represented in this sample, it is difficult to be certain that the results give a truly clear picture of the skills required in those sectors. Further research would be required, over a longer period, of vacancies in those less wellrepresented sectors, to gain a more accurate picture of the skills in demand.

\begin{tabular}{|c|c|c|c|c|c|c|}
\hline & $\begin{array}{l}\text { Teaching/ } \\
\text { user } \\
\text { education }\end{array}$ & $\begin{array}{l}\text { Enquiry/ } \\
\text { reference } \\
\text { skills }\end{array}$ & $\begin{array}{l}\text { Cataloguing } \\
\text { skills }\end{array}$ & $\begin{array}{l}\text { Specialised } \\
\text { database } \\
\text { knowledge }\end{array}$ & $\begin{array}{l}\text { Web page } \\
\text { writing } \\
\text { skills } \\
\end{array}$ & \begin{tabular}{|l|} 
Stock \\
selection
\end{tabular} \\
\hline \multicolumn{7}{|l|}{ Education } \\
\hline $\mathrm{HE}$ & 23 & 21 & 18 & 12 & 10 & 9 \\
\hline FE & 22 & 24 & 15 & 10 & 6 & 12 \\
\hline Schools & 21 & 0 & 1 & 4 & 3 & 3 \\
\hline Education & 11 & 33 & 11 & 11 & 22 & 11 \\
\hline \multicolumn{7}{|l|}{ Public Sector } \\
\hline Prisons and police & 30 & 20 & 10 & 10 & 10 & 10 \\
\hline Museums & 9 & 27 & 36 & 9 & 18 & 9 \\
\hline Public & 8 & 8 & 4 & 2 & 3 & 13 \\
\hline Government & 8 & 29 & 17 & 8 & 27 & 4 \\
\hline National libraries & 7 & 43 & 29 & 7 & 14 & 7 \\
\hline \multicolumn{7}{|l|}{ Health } \\
\hline NHS/Health & 38 & 20 & 7 & 30 & 12 & 16 \\
\hline \multicolumn{7}{|l|}{ Other } \\
\hline Not stated & 41 & 38 & 39 & 35 & 36 & 38 \\
\hline Other & 25 & 25 & 25 & 25 & 25 & 25 \\
\hline Charity & 10 & 40 & 20 & 15 & 20 & 5 \\
\hline Professional Bodies & 11 & 56 & 28 & 6 & 17 & 33 \\
\hline \multicolumn{7}{|l|}{ Commercial Sector } \\
\hline Private & 26 & 41 & 39 & 31 & 24 & 24 \\
\hline Law & 18 & 27 & 11 & 4 & 13 & 13 \\
\hline Media & 13 & 50 & 38 & 13 & 13 & 13 \\
\hline Finance & 8 & 85 & 8 & 8 & 8 & 8 \\
\hline Entire sample & 17 & 20 & 12 & 10 & 9 & 10 \\
\hline
\end{tabular}

Table 2 Percentage of Library Specific Skills in sample divided by sector 
In the education sector, teaching and user education is specified in almost a quarter of vacancies in $\mathrm{HE}$ (statistically the most significant sector in the overall sample in terms of number of posts), and just over a tenth of posts in education. This skill is also important in Fe and schools, at just over a fifth of all posts. Enquiry and reference skills are also important in all subsets of this sector except for schools. Cataloguing skills are requested in just under a fifth of posts in HE, in over a tenth of posts in FE and education, and appear to be negligible in the schools sector.

\section{Overall analysis of skills requested: general management skills}

The chart below gives percentages for the entire sample of vacancies which specified management skills. General management skills were specified in over a quarter of all vacancies $(26 \%)$.

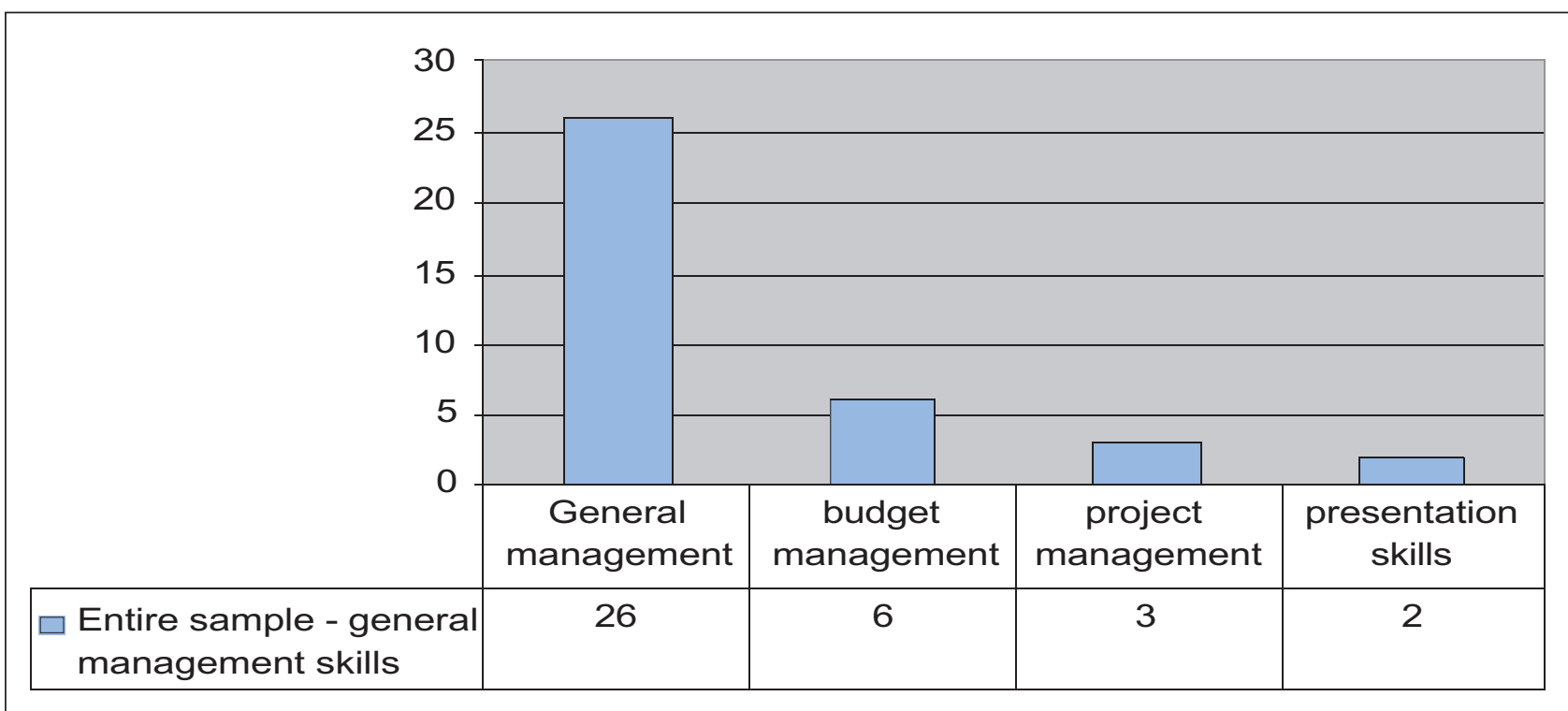

Fig. 2 Percentage of General Management Skills requested - complete sample

The table below shows, for each sector, what percentage of advertisements in particular sectors specified a particular management skill.

\begin{tabular}{|l|r|r|r|r|}
\hline & $\begin{array}{l}\text { General } \\
\text { management }\end{array}$ & $\begin{array}{l}\text { ludget } \\
\text { management }\end{array}$ & $\begin{array}{l}\text { project } \\
\text { management }\end{array}$ & \multicolumn{1}{l|}{$\begin{array}{l}\text { presentation } \\
\text { skills }\end{array}$} \\
\hline Education & & 11 & 11 & 11 \\
\hline Education & 33 & 6 & 2 & 3 \\
\hline FE & 33 & 4 & 4 & 2 \\
\hline HE & 27 & 4 & 1 & 0 \\
\hline Schools & 21 & & & 11 \\
\hline & & & & 1 \\
\hline Public Sector & & 11 & 11 & 2 \\
\hline Prisons and police & 33 & 11 & 4 & 9 \\
\hline Public & 32 & 2 & 2 & 7 \\
\hline Government & 27 & 9 & 9 & 7 \\
\hline Museums & 27 & 7 & & \\
\hline National libraries & 7 & &
\end{tabular}




\begin{tabular}{|c|c|c|c|c|}
\hline & $\begin{array}{l}\text { General } \\
\text { management }\end{array}$ & $\begin{array}{l}\text { Budget } \\
\text { management }\end{array}$ & \begin{tabular}{|l|} 
project \\
management
\end{tabular} & $\begin{array}{l}\text { presentation } \\
\text { skills }\end{array}$ \\
\hline \multicolumn{5}{|l|}{ Health } \\
\hline NHS/Health & 27 & 9 & 4 & 5 \\
\hline \multicolumn{5}{|l|}{ Other } \\
\hline Other & 40 & 10 & 10 & 10 \\
\hline Charity & 31 & 20 & 19 & 20 \\
\hline Not stated & 25 & 25 & 25 & 25 \\
\hline Professional Bodies & 25 & 10 & 5 & 5 \\
\hline \multicolumn{5}{|l|}{ Commercial Sector } \\
\hline Private & 44 & 33 & 33 & 33 \\
\hline Finance & 15 & 15 & 8 & 8 \\
\hline Media & 13 & 13 & 13 & 13 \\
\hline Law & 4 & 2 & 1 & 0 \\
\hline Entire sample & 26 & 6 & 3 & 2 \\
\hline
\end{tabular}

Table 3 Percentage of General Management Skills in sample divided by sector

All management skills are proportionately more important in the private sector than in any other sector. General management and budget management are least likely to be requested in law; project management and presentation skills are least likely to be requested in law and schools.

\section{Overall analysis of skills requested: transferable skills, customer facing}

The chart below gives percentages for the entire sample of vacancies which specified transferable skills in customer-facing areas. Communications skills were specified in over a third of all vacancies $(35 \%)$.

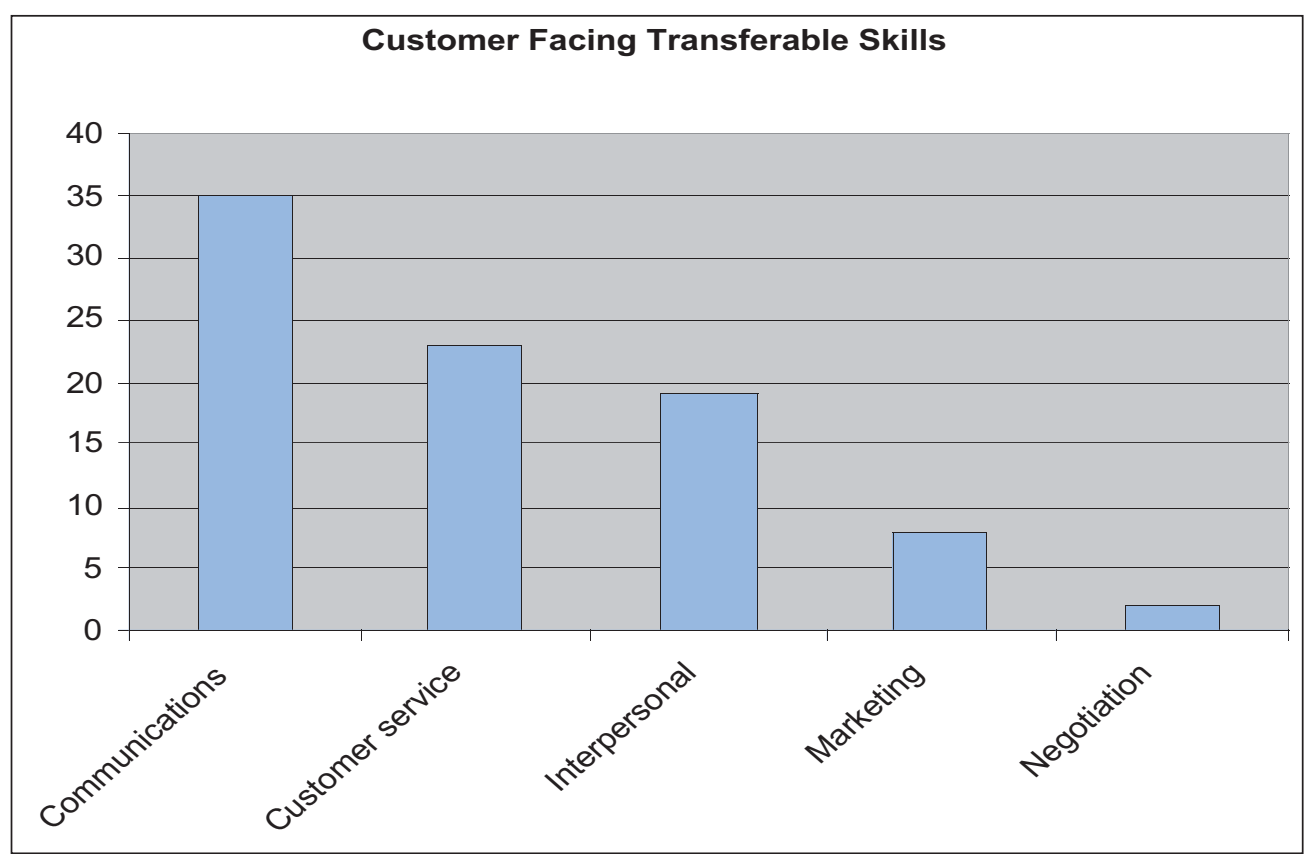

Fig. 3 Percentage of customer facing transferable skills requested - complete sample 
The table below shows, for each sector, what percentage of advertisements in particular sectors specified a particular transferable skill in customer-facing areas.

In the education sector, communications skills appear to be most in demand in the FE area, followed by HE, and least in demand in schools - although it should be remembered that the advertisements for school librarians are in general the least detailed. In the public sector, communications skills appear to be particularly important for the police, followed by museums, and less important in government posts. Over half of NHS/Health posts in this sample specified communications skills. Although the 'other' category appears to be a particularly important sector, it should be remembered that there are very few posts in this category.

Similarly, although over half of posts in the 'not stated' category specify communications, it is difficult to draw any conclusions from this owing to the very diverse range of employers in this sector.

Interpersonal skills are important in at least $15 \%$ (schools) and at most 27\% (HE) of the posts in education. In the public sector, these skills are important in just over a tenth of national government posts $(12 \%)$ and in just under a third of posts in prisons and the police (30\%). Just under a fifth of health library posts advertised in this sample specify interpersonal skills. As with communications skills, although on the surface the 'other' category appears to find interpersonal skills particularly important, numerically the posts in this area are so few that it is difficult to draw any sensible conclusions from this survey.

\begin{tabular}{|c|c|c|c|c|c|}
\hline & Communications & Interpersonal & \begin{tabular}{|l} 
Customer \\
services
\end{tabular} & Marketing & Negotiation \\
\hline \multicolumn{6}{|l|}{ Education } \\
\hline FE & 45 & 24 & 22 & 2 & 1 \\
\hline $\mathrm{HE}$ & 39 & 27 & 26 & 4 & 2 \\
\hline Education & 33 & 22 & 33 & 11 & 11 \\
\hline Schools & 19 & 15 & 1 & 6 & 0 \\
\hline \multicolumn{6}{|l|}{ Public Sector } \\
\hline Prisons and police & 60 & 30 & 20 & 10 & 20 \\
\hline Museums & 45 & 27 & 36 & 9 & 9 \\
\hline National libraries & 36 & 29 & 57 & 7 & 7 \\
\hline Public & 31 & 14 & 29 & 15 & 4 \\
\hline Government & 19 & 12 & 31 & 6 & 2 \\
\hline \multicolumn{6}{|l|}{ NHS/Health } \\
\hline NHS/Health & 51 & 19 & 26 & 14 & 4 \\
\hline \multicolumn{6}{|l|}{ Other } \\
\hline Other & 75 & 50 & 25 & 25 & 25 \\
\hline Professional Bodies & 67 & 22 & 22 & 6 & 6 \\
\hline Not stated & 62 & 44 & 52 & 36 & 30 \\
\hline Charity & 30 & 10 & 25 & 10 & 10 \\
\hline \multicolumn{6}{|l|}{ Commercial Sector } \\
\hline Private & 43 & 30 & 33 & 20 & 20 \\
\hline Finance & 31 & 8 & 8 & 15 & 8 \\
\hline Law & 16 & 11 & 43 & 7 & 2 \\
\hline Media & 13 & 13 & 13 & 13 & 13 \\
\hline Entire sample & 35 & 19 & 23 & 8 & 2 \\
\hline
\end{tabular}

Table 4 Percentage of customer-facing transferable skills by sector 


\section{Overall analysis of skills requested:} transferable skills, non-customer facing

The chart below gives percentages for the entire sample of vacancies which specified transferable skills in non-customer-facing areas.
ICT skills (not including specialised databse knowledge) were specified in $40 \%$ of all vacancies, by far the most frequently requested skill.

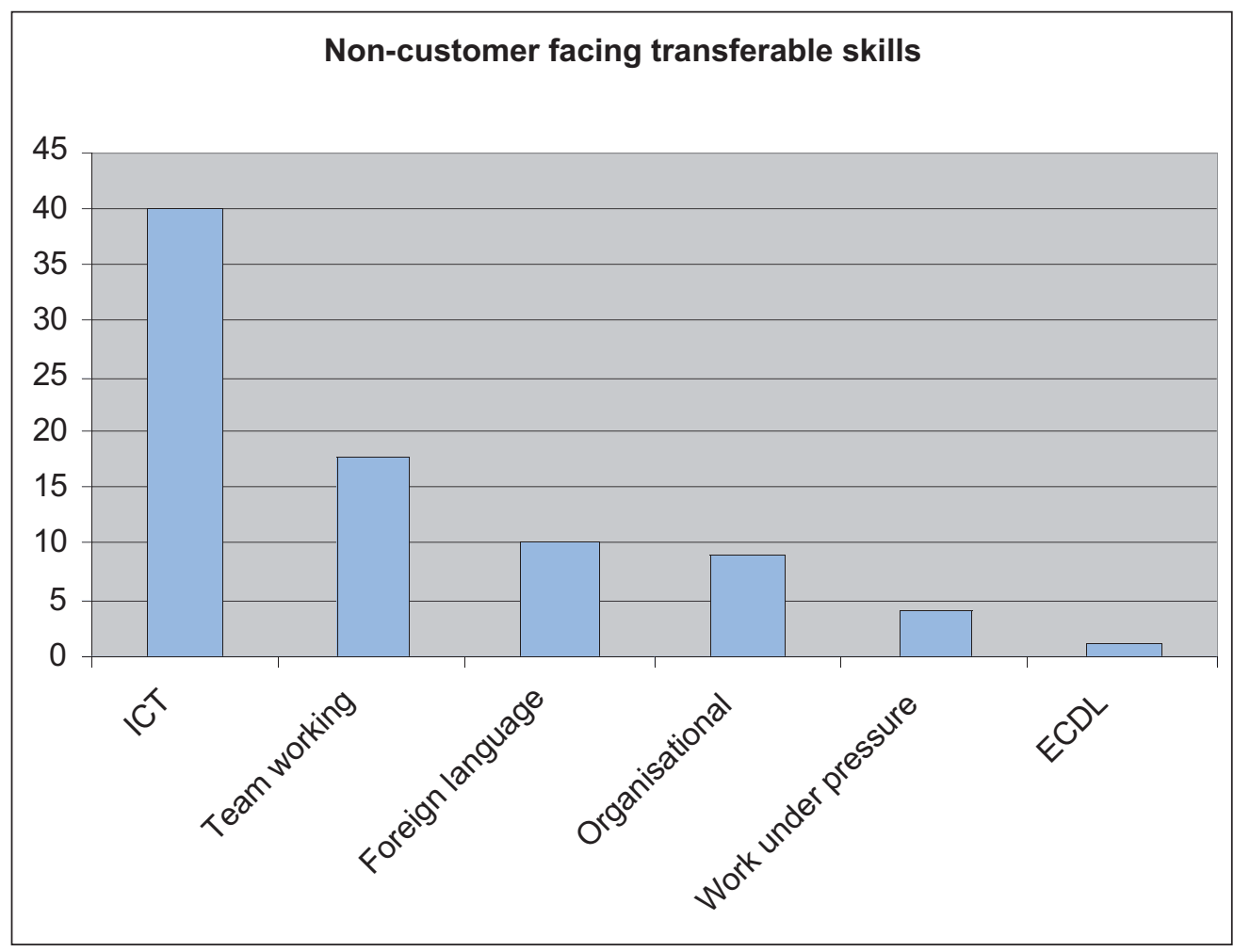

Fig. 4 Percentage of non-customer facing transferable skills requested - complete sample

The table below shows, for each sector, what percentage of specified a particular transferable skill in non- customer-facing areas. ICT skills were proportionately most important in law.

Organisational skills were most important to the prisons and police sector.

\begin{tabular}{|c|c|c|c|c|c|c|}
\hline & ICT & $\begin{array}{l}\text { Team } \\
\text { working }\end{array}$ & Organisational & $\begin{array}{l}\text { Work under } \\
\text { pressure }\end{array}$ & $\begin{array}{l}\text { Foreign } \\
\text { language }\end{array}$ & ECDL \\
\hline \multicolumn{7}{|l|}{ Education } \\
\hline $\mathrm{FE}$ & 58 & 23 & 9 & 5 & 2 & 1 \\
\hline Education & 56 & 22 & 22 & 11 & 22 & 11 \\
\hline $\mathrm{HE}$ & 46 & 20 & 7 & 5 & 4 & 0 \\
\hline Schools & 46 & 7 & 1 & 0 & 0 & 0 \\
\hline \multicolumn{7}{|l|}{ Public Sector } \\
\hline Museums & 55 & 18 & 15 & 9 & 18 & 9 \\
\hline Prisons and police & 40 & 10 & 50 & 10 & 20 & 10 \\
\hline Public & 34 & 17 & 10 & 5 & 0 & 3 \\
\hline Government & 33 & 15 & 2 & 4 & 4 & 2 \\
\hline National libraries & 7 & 24 & 7 & 7 & 21 & 7 \\
\hline
\end{tabular}




\begin{tabular}{|c|c|c|c|c|c|c|}
\hline & ICT & \begin{tabular}{|l} 
Team \\
working
\end{tabular} & Organisational & $\begin{array}{l}\text { Work under } \\
\text { pressure }\end{array}$ & $\begin{array}{l}\text { Foreign } \\
\text { language }\end{array}$ & ECDL \\
\hline \multicolumn{7}{|l|}{ Health } \\
\hline NHS/Health & 47 & 9 & 12 & 1 & 0 & 3 \\
\hline \multicolumn{7}{|l|}{ Other } \\
\hline Not stated & 64 & 44 & 39 & 32 & 67 & 30 \\
\hline Other & 50 & 75 & 25 & 25 & 50 & 25 \\
\hline Professional Bodies & 44 & 17 & 11 & 6 & 11 & 6 \\
\hline Charity & 25 & 20 & 5 & 5 & 10 & 5 \\
\hline \multicolumn{7}{|l|}{ Commercial } \\
\hline Law & 86 & 16 & 13 & 7 & 67 & 0 \\
\hline Private & 50 & 39 & 28 & 20 & 43 & 17 \\
\hline Finance & 15 & 31 & 8 & 8 & 15 & 8 \\
\hline Media & 13 & 13 & 13 & 25 & 25 & 13 \\
\hline Entire sample & 40 & 18 & 9 & 4 & 10 & 1 \\
\hline
\end{tabular}

Table 5 Percentage of non customer-facing transferable skills by sector

\section{Skills by job title}

The job titles of posts were recorded in the database exactly as they appeared in the header of the advertisements. There were 665 unique job titles in this sample, although there were several job titles which had a common component, e.g. Clinical Librarian and Clinical Librarian (Mental Health), or Information Skills Trainer and Information Skills Training Officer.

The vacancies were divided into the following categories, based on job title.

- Library Assistant (including Graduate trainees where the post is offered prior to library school applications)

- Senior Paraprofessional e.g. Senior Library Assistant

- Professional - Assistant Librarian (incorporating trainee posts where the applicant is required to have completed a postgraduate or first degree level library or information science course)

- Professional - Librarian, including subject and departmental librarians. Although in Academia subject librarians may often be known as Assistant Librarians, in this sample only 2 of the posts advertised carried this title. Three further posts, which carried the title Trainee Assistant Subject Librarian, were included in the Assistant Librarian category. Of the 198 posts in this sample which specified 2-5 years experience, only 7 had Assistant Librarian in their title. For comparison, 78 of the posts requesting this amount of experience were for Librarians. For this reason, Assistant Librarian and Librarian posts have been analysed separately.

- Manager - where manager was part of the job title

- Senior Librarian - including e.g. Head of Library Services

- Researcher/specialist - this category includes those posts which do not easily fit into any of the other categories, e.g. Project Co-ordinator, Portal Content Manager, and Researchers.

- Director and above

The chart below shows the percentage of vacancies in each of these categories in this sample: 


\begin{tabular}{|l|r|}
\hline Level of Post & \%age of vacancies in this sample \\
\hline Librarian & 36 \\
\hline Manager & 20 \\
\hline Researcher and specialist & 15 \\
\hline Assistant Librarian & 12 \\
\hline Library Assistant & 7 \\
\hline Senior Librarian & 6 \\
\hline Senior paraprofessional & 3 \\
\hline Director and above & 1 \\
\hline
\end{tabular}

Table 6 Percentage of posts by sector

In this sample, over a third of the posts advertised were at Librarian Level, with the next nearest category, manager, accounting for one-fifth of posts. Researchers and specialist posts accounted for $15 \%$ of vacancies. Assistant Librarian vacancies accounted for only $12 \%$ of the posts advertised in this sample: or, to put it another way, there are three times as many vacancies at the Librarian level as there are at the Assistant Librarian level in this sample. Senior Librarian vacancies accounted for only $6 \%$ of the posts advertised in this sample: or, to rephrase again, there were six times as many vacancies at Librarian level as at Senior Librarian level.

\section{Skills by level: general management}

The table below gives percentages of management skills requested across the levels. As might be expected, the higher the level, the more important are general management skills, although even at library assistant level some posts expect a level of general management ability.

\begin{tabular}{|l|r|l|l|l|}
\hline & $\begin{array}{l}\text { Budget } \\
\text { management }\end{array}$ & $\begin{array}{l}\text { General } \\
\text { management }\end{array}$ & $\begin{array}{l}\text { Project } \\
\text { management }\end{array}$ & Presentation \\
\hline Library Assistant & 0 & 4 & 0 & 0 \\
\hline Senior paraprofessional & 3 & 10 & 0 & 7 \\
\hline Assistant Librarian & 3 & 14 & 2 & 2 \\
\hline Librarian & 6 & 21 & 2 & 2 \\
\hline Senior Librarian & 11 & 48 & 0 & 3 \\
\hline Manager & 12 & 54 & 5 & 1 \\
\hline Researcher/specialist & 3 & 10 & 7 & 3 \\
\hline Director and above & 22 & 67 & 0 & 0 \\
\hline
\end{tabular}

Table 7 Percentage of posts requiring management skills by level of post 


\section{Skills by level: specialised library skills}

The table below gives percentages across the various levels of posts for library skills.

\begin{tabular}{|c|c|c|c|c|c|c|c|}
\hline & ICT & Cataloguing & Web page & Enquiry & \begin{tabular}{|l|} 
Stock \\
selection
\end{tabular} & $\begin{array}{l}\text { Specialised } \\
\text { database }\end{array}$ & \begin{tabular}{|l} 
Teaching/ \\
user ed
\end{tabular} \\
\hline $\begin{array}{l}\text { Library } \\
\text { Assistant }\end{array}$ & 45 & 13 & 4 & 31 & 3 & 6 & 3 \\
\hline $\begin{array}{l}\text { Senior } \\
\text { paraprofessional }\end{array}$ & 62 & 24 & 7 & 28 & 7 & 10 & 17 \\
\hline $\begin{array}{l}\text { Assistant } \\
\text { Librarian }\end{array}$ & 46 & 18 & 12 & 26 & 26 & 15 & 20 \\
\hline Librarian & 39 & 16 & 10 & 20 & 12 & 11 & 20 \\
\hline $\begin{array}{l}\text { Senior } \\
\text { Librarian }\end{array}$ & 31 & 0 & 3 & 3 & 8 & 2 & 8 \\
\hline Manager & 38 & 8 & 6 & 13 & 11 & 7 & 16 \\
\hline $\begin{array}{l}\text { Researcher/ } \\
\text { specialist }\end{array}$ & 43 & 7 & 12 & 23 & 4 & 12 & 20 \\
\hline $\begin{array}{l}\text { Director } \\
\text { and above }\end{array}$ & 11 & 0 & 11 & 0 & 0 & 0 & 0 \\
\hline
\end{tabular}

Table 8 Percentage of posts requiring management skills by level of post

ICT skills and enquiry skills appear to be proportionately more important at the level of library assistant and senior paraprofessional. ICT skills and enquiry skills are least important at director and above level. Cataloguing is proportionately more important for senior paraprofessionals and least important for senior librarians. The ability to write web pages and select stock, together with specialised database knowledge, becomes more important for assistant librarians, librarians, researchers/specialists, and directors, and least important at the senior librarian level.

Specialised database skills are most important for assistant librarians, and least important at director level. Teaching/user education becomes more important for assistant librarians, librarians, and researchers/specialists and is least important for directors.

\section{Transferable skills - customer-facing}

As can be seen from the table below, communication skills are proportionately most important for senior paraprofessionals, and least important for assistant librarians - although even for assistant librarian posts communication skills are specified in almost a third of vacancies in this sample.

Customer services skills are most likely to be requested in library assistant vacancies, and least likely to be requested at the level of director and above. Marketing skills are most likely to be found in librarian vacancies and least likely to be requested at paraprofessional and director level.

Negotiation skills, on the other hand, are most likely to be requested at director level, and not found at all in library assistant, senior paraprofessional or senior librarian posts in this sample. Interpersonal skills are most likely to be requested in senior paraprofessional vacancies, and least likely to be requested in researcher/specialist roles - although even here they are still specified in $16 \%$ of vacancies. 


\begin{tabular}{|l|r|r|r|r|r|}
\hline & Communication & $\begin{array}{l}\text { Customer } \\
\text { Services }\end{array}$ & Marketing & Negotiation & $\begin{array}{l}\text { Interpersonal } \\
\text { Skills }\end{array}$ \\
\hline Library Assistant & 31 & 44 & 3 & 0 & 18 \\
\hline Senior Paraprofessional & 55 & 34 & 0 & 0 & 24 \\
\hline Assistant Librarian & 30 & 29 & 6 & 1 & 23 \\
\hline Librarian & 36 & 22 & 10 & 1 & 18 \\
\hline Senior Librarian & 33 & 13 & 9 & 0 & 17 \\
\hline Manager & 32 & 19 & 8 & 6 & 19 \\
\hline Researcher/specialist & 38 & 19 & 10 & 2 & 16 \\
\hline Director and above & 33 & 11 & 0 & 11 & 22 \\
\hline
\end{tabular}

Table 9 Percentage of posts requiring customer-facing transferable skills by level of post

\section{Transferable skills - other}

In this skills area, both the graph and the table illustrate that enthusiasm is most likely to be specified in posts for senior librarians, and least likely to be requested at director level and above. The ability to work under pressure is most likely to be found at the senior paraprofessional level, and least likely to be found explicitly requested at director level. Teamwork,

To judge by the data in this sample, enthusiasm is most important for senior librarians, and least important for those at director level. The ability to work under pressure is most important for senior paraprofessionals, and least important for directors. Conversely, the ability to work in teams is most important for directors, and least important for library assistants. Organisational skills, on the other hand, are most important for library assistants and least important for directors. It is most important that senior librarians are flexible, and least important for directors. The European Computer Driving Licence is requested in at most $2 \%$ and at the least $0 \%$ of vacancies. Posts requiring foreign languages are most likely to be at the senior paraprofessional level, and least likely to be at senior librarian or director level.

\begin{tabular}{|l|r|r|r|r|r|r|r|}
\hline & Enthusiasm & $\begin{array}{l}\text { Work under } \\
\text { pressure }\end{array}$ & $\begin{array}{l}\text { Team } \\
\text { work }\end{array}$ & organisational & $\begin{array}{l}\text { flexibility } \\
\text { languages }\end{array}$ & ECDL & Foreign \\
\hline Library Assistant & 13 & 6 & 8 & 13 & 4 & 0 & 7 \\
\hline Senior & 17 & 10 & 24 & 3 & 0 & 0 & 14 \\
paraprofessional & & & & & & & \\
\hline Assistant Librarian & 18 & 5 & 18 & 11 & 3 & 1 & 2 \\
\hline Librarian & 31 & 4 & 19 & 10 & 6 & 2 & 3 \\
\hline Senior Librarian & 42 & 5 & 19 & 8 & 9 & 2 & 0 \\
\hline Manager & 27 & 3 & 18 & 7 & 5 & 0 & 1 \\
\hline Researcher/specialist & 22 & 4 & 19 & 7 & 7 & 1 & 3 \\
\hline Director and above & 0 & 0 & 33 & 0 & 0 & 0 & 0 \\
\hline
\end{tabular}

Table 10 Percentage of posts requiring non-customer facing transferable skills by level of post 


\section{Chartered or qualified?}

For a qualified librarian, the next stage in career development is often to charter.

In this sample, chartership was mentioned in less than $10 \%$ of vacancies as an entry requirement or a factor that would result in a higher salary. The sector most likely to request a chartered librarian was the public sector, with 52 of the 98 adverts $(53 \%)$ that mentioned chartership being from the public libraries sector.

\section{Chartership by level}

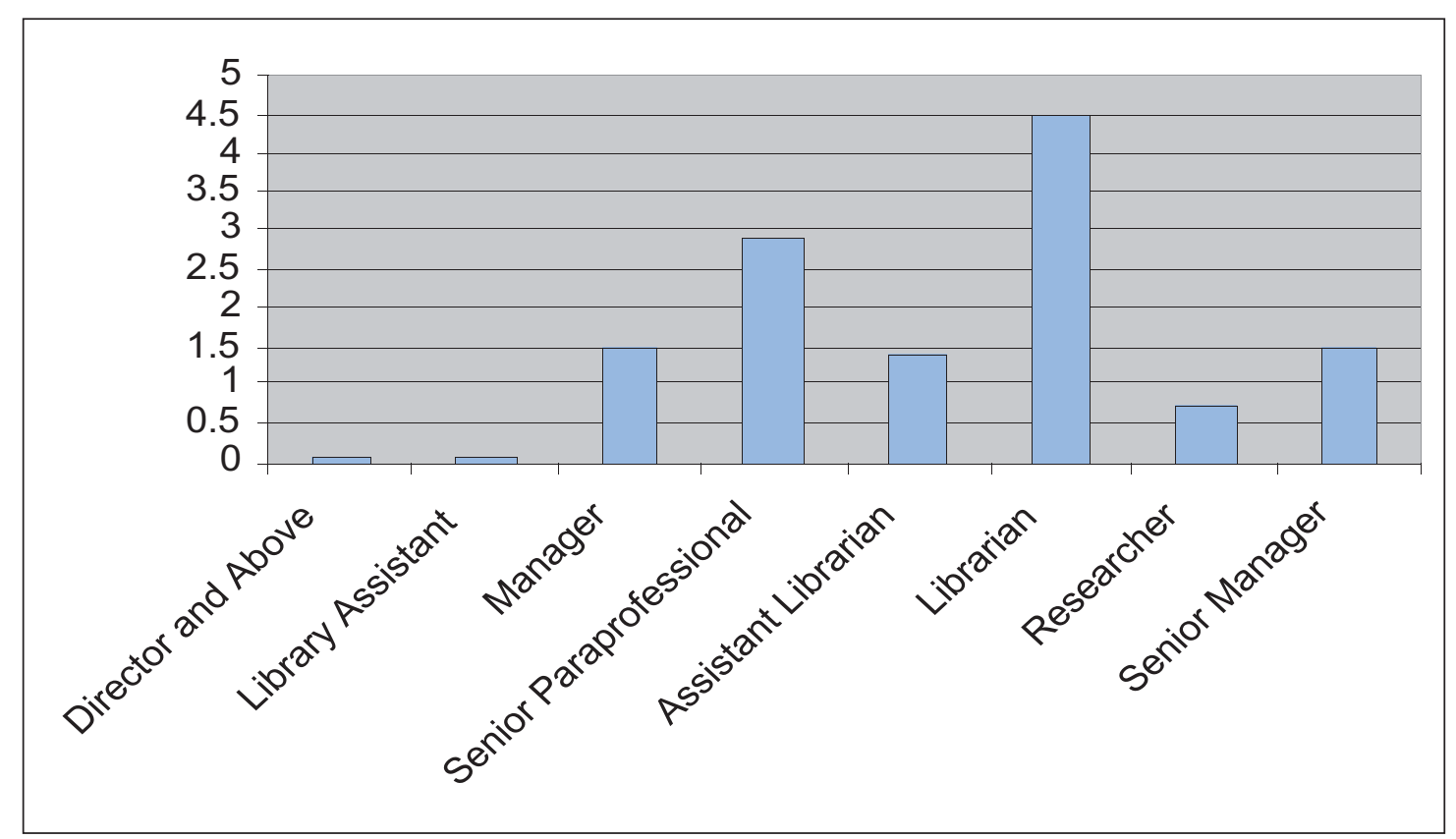

Fig. 5 Percentage of advertisements by level requiring chartership - complete sample

In this sample, chartership is specified in more than one per cent of only four of the seven categories. The most likely level of post to request chartership is that of Librarian, though even there it is only requested in $4.5 \%$ of posts.
At Library Assistant level, only one post requests chartership, though this is not so surprising as the fact that at Director level and above the percentage is identical.

\begin{tabular}{|l|r|r|}
\hline & Number & Percentage \\
\hline Director and Above & 1 & 0.1 \\
\hline Library Assistant & 1 & 0.1 \\
\hline Senior Paraprofessional & 29 & 2.9 \\
\hline Manager & 15 & 1.5 \\
\hline Assistant Librarian & 14 & 1.4 \\
\hline Librarian & 45 & 4.5 \\
\hline Researcher & 7 & 0.7 \\
\hline Senior Manager & 15 & 1.5 \\
\hline
\end{tabular}

Table 11 Percentage of posts requiring non-customer facing transferable skills by level of post 


\section{Chartered by sector}

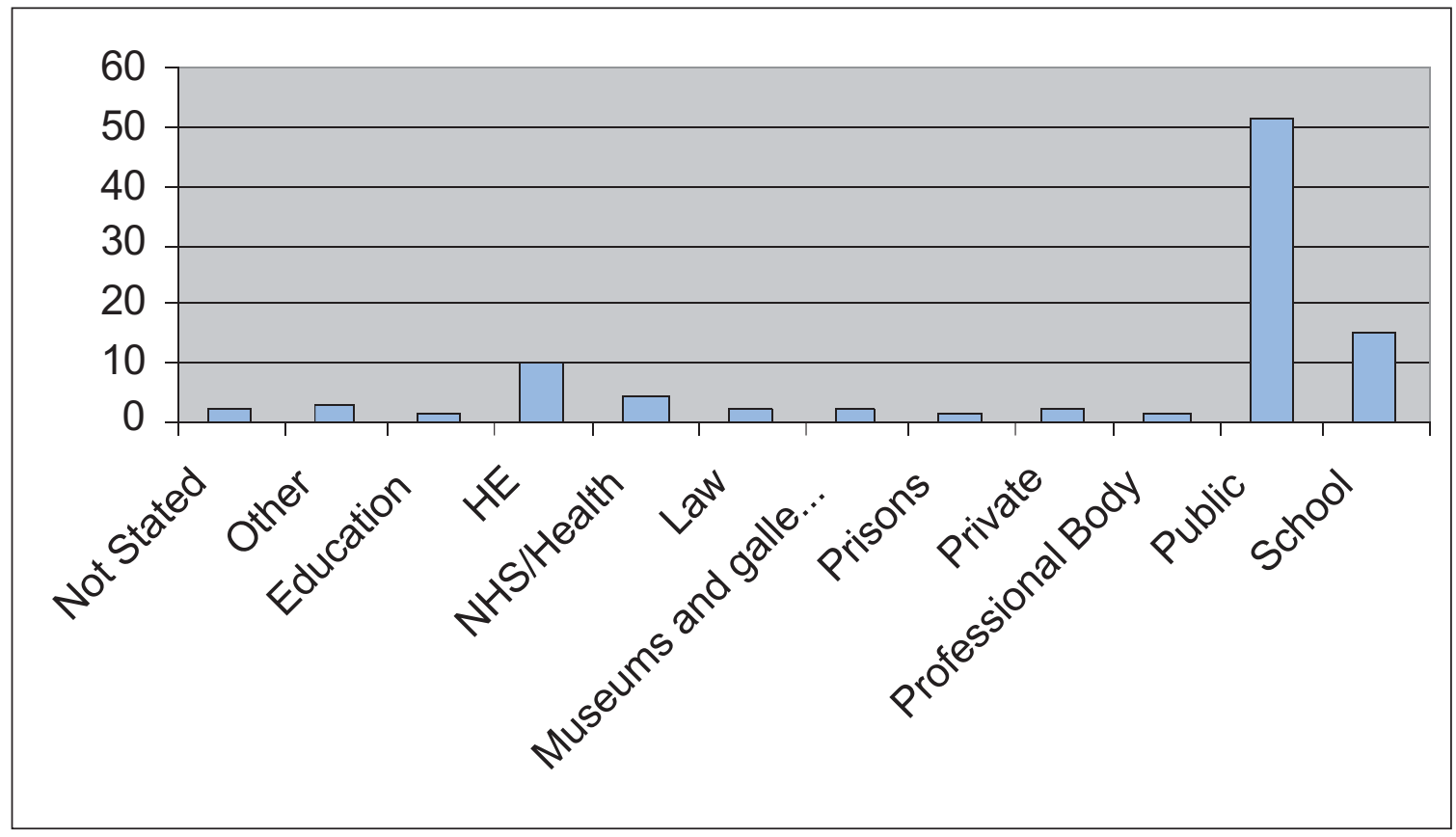

Fig. 6 Percentage of advertisements by sector requiring chartership - complete sample

\begin{tabular}{|c|c|c|}
\hline & Number & \% age of sample \\
\hline \multicolumn{3}{|l|}{ Education } \\
\hline School & 15 & 1.5 \\
\hline $\mathrm{HE}$ & 10 & 1 \\
\hline Education & 1 & 0.1 \\
\hline \multicolumn{3}{|l|}{ Public Sector } \\
\hline Museums & 2 & 0.2 \\
\hline Prisons and police & 1 & 0.1 \\
\hline Public & 52 & 5.2 \\
\hline \multicolumn{3}{|l|}{ Health } \\
\hline NHS/Health & 4 & 0.4 \\
\hline \multicolumn{3}{|l|}{ Other } \\
\hline Not Stated & 2 & 0.2 \\
\hline Other & 3 & 0.3 \\
\hline \multicolumn{3}{|l|}{ Private } \\
\hline Law & 2 & 0.2 \\
\hline Private & 2 & 0.2 \\
\hline Professional Body & 1 & 0.1 \\
\hline
\end{tabular}

Table 12 Percentage of posts requiring non-customer facing transferable skills by level of post 


\section{Some observed trends}

ICT skills are the most frequently requested overall by employers, particularly if specialised library catalogue or systems administrator experience is included. Many job adverts, however, leave the reader to extrapolate which skills are actually required. Schools are particularly weak at specifying which skills they need. This may be due to the fact that advertisements are sold by number of column inches. At 2005 costs, the cheapest advertisement in Gazette, for example, for mono $1 / 16$ th of a page, is $£ 365$, with half-page advertisements running at almost $£ 3,000$, and full-page colour advertisements costing the advertiser $£ 5855$. In addition, School Library advertisements may be compiled by an administrative officer, teaching professional, or local government employee who is not a specialist in this area.

Where chartership is concerned, the public library sector is most likely to ask for a chartered librarian, which makes a difference to the salary. From the data in this sample however the public library sector also appears to be the lowest paid. Over $51 \%$ of public library posts in this sample pay less than $£ 20 \mathrm{~K}$ per annum, compared to $43 \%$ of HE posts and $48 \%$ of government vacancies.

\section{Implications for individuals}

As mentioned above, ICT skills still seem to be in high demand. Proof of ICT ability, therefore, would seem to be a valuable asset. The ECDL, although an internationally recognised qualification throughout Europe, and endorsed by the British Computer Society, is only specified in 11 posts in the entire sample (1\%), although ICT ability is requested in 404 (40\%). The European Computer Driving Licence is equivalent to an NVQ Level 2, or GCSE qualification. This may mean that for some library posts it is a little too basic. There does not, however, appear to be a more formal ICT qualification at a higher level than this unless you look at more formal qualifications such as a bachelor's degree or above. Communication is the most valued 'soft skill'.
The majority of vacancies (over a third) are in London. If the South-East is included, this increases to almost half of all LIS vacancies. This seems to be particularly true of entry-level posts. Over $61 \%$ of vacancies in the south-east and London (344/560) were suitable for those with less than 2 years experience.

Higher Education remains the sector with most vacancies overall, followed by the public sector. For those wishing to specialise, there are comparatively fewer posts and many require sector-specific experience, suggesting that once you have specialised in a sector, it is extremely difficult to change. This theory would, however, benefit from more structured research.

\section{Implications for employers}

If the advertisements in this sample can be taken to be representative of the needs of LIS employers, there are three times as many professional vacancies at librarian level (36\% of sample) as there are at assistant librarian level (12\% of sample). A further fifth of vacancies require managers of some description. Employers may therefore need to look at recruiting from within to fill these vacancies effectively. To draw out this talent they may need to consider offering incentives in the way of training, mentoring schemes, or talentspotting schemes such as those found in some parts of the public sector.

In areas of relatively high job choice (such as the south-east), employers may need to be aware that good candidates can afford to be very selective. Where salaries are relatively low compared to similar posts, it may be necessary to sell the vacancy using other advantages of working for the employer.

It may be necessary for employers to start thinking about internal schemes to mentor and identify future leaders as suggested by Singer et al in their Library Journal analysis of the situation (2004). 


\section{Suggestions for future research}

The research raises several areas for possible future research. What proportion of librarians, for example, fall into the Baby

Boomers/Generation X/Generation Y categories and what implications does this have for the next $10-15$ years in the library profession? What proportion of these jobs are likely to be replaced by new technology?

It would be interesting to conduct a study into what proportion of qualified librarians are under-employed, or finding themselves sidelined or stymied. In the UK Civil Service, for example, the entry level grade is Band D/Executive Officer. How many years on average do entrants spend there before either being promoted internally or moving to another part of the civil service, and what proportion are able to be promoted internally without changing disciplines or locations? What proportion of library assistants have LIS degrees or postgraduate diplomas?

It would also be interesting to assess what proportion of non-library graduates are filling what have traditionally been graduate librarian posts. Finally, is the geographical clustering of LIS posts in the south-east a true picture or a reflection of the fact that many provincial employers see CILIP as a south-focused organisation and advertise their posts elsewhere?

\section{References}

American Library Association (2005), ALA Placement Center Statistics, Midwinter Statistics 1974 - Present URL: http://www.ala.org/ala/hrdr/placementservice/placement center.htm [28 May 2005]

American Library Assocation (2002), Library profession faces shortage of librarians: Key facts and figures from the American Library Association, URL:

http://www.ala.org/ala/pio/piopresskits/recruitpresskit/li braryprofession.htm [28 May 2005]

Bentley, Tom (2004), It's boom time, Guardian I March 2004, URL:

http://society.guardian.co.uk/managingnewrealities/story 10,14030,1165540,00.html

Goulding, A et al (1999)., Likely to Succeed:Attitudes and Aptiitudes for an Effective Information Profession in the 2 Ist Century, Report 8 , Library \& Information

Commission .

Hamblin, Yvonne (2002), North West Library and Archive Labour Market Information Report to North West Museums Service, North West Regional Archive Council and Libraries North West. URL:

http://www.northwestarchives.org.uk/NWreportNov02 .pdf [28 May 2005]

Jacobson (2002), A Shortage of Academic Librarians, Chronicle of Higher Education URL: http://chronicle.com/jobs/2002/08/200208I40Ic.htm [28 May 2005]

Lankard, Bettina A. (1995) Career Development in Generation X,World of Education, URL: http://library.educationworld.net/a2/a2-16.html [28 May 2005]

Lynch, Mary Jo, Reaching 65: Lots of Librarians Will Be There Soon, American Libraries, March 2002, pp. 55-56 URL: http://archive.ala.org/alonline/archive/reaching65.pdf [28 May 2005]

Nexgen Librarian Weblog (2005), Not the Only One, URL: http://www.nexgenlibrarian.net/2005/0l/not-onlyone-caveat-lector-doesnt.html [28 May 2005]

Rodgers, Matt (2004) Gen X Marks Its Spot, ClO URL: http://www.cio.com.au/pp.php?id=1535508883\&fp $=4 \& f p$ id=I [28 May 2005]

Semlac (2004), Realising Our Potential: A Library and Information Development Strategy for the South East 2002 - 2006 - Appendices, URL:

http://www.semlac.org.uk/library-strategy/appendices librarystrategy.doc [28 May 2005] 
Singer et al (2004) Your Library's Future, Library Journal 2004, URL:

http://www.libraryjournal.com/article/CA470985.html [28 May 2005]

Teece (2003), The library labour market in Australia, URL: http://www.alia.org.au/publishing/slideshows/200309a/ [28 May 2005]

Usherwood et al (200I), Recruit, Retain and Lead:The Public Library Workforce Study, Centre for the Public Library and Information in Society, Department of Information Studies, The University of Sheffield, Re:Source The Council for Museums, Archives and Libraries, 200I URL:

http://cplis.shef.ac.uk/workforce.pdf [28 May 2005]

Unison Submission To The House Of Commons Culture Media And Sport Committee Inquiry Into Government Policy On Public Libraries (200I?). URL:

http://Www.Unison.Org.Uk/Acrobat/BI654.pdf

Whitmell,Vicki (2002) Facing the challenges of an aging population : succession planning strategies for libraries and information management organizations. Presentation to the VitalLink 3 Conference, Adelaide Australia, November 2002. URL:

http://www.whitmell.com/libraries/aus speech.pdf

Wilder, Stanley (2000), The Changing Profile of Research Library Professional Staff, ARL :A Bimonthly Report on Research Library Issues and Actions from ARL, CNI, and SPARC, 208/209. URL:

http://www.arl.org/newsltr/208 209/chgprofile.html [28 May 2005] 